\title{
Mitigation of lethal effects of Karlodinium veneficum and $K$. armiger on Sparus aurata: changes in haematocrit and plasma osmolality
}

\author{
Margarita Fernández-Tejedor*, M. Ángeles Soubrier-Pedreño, M. Dolores Furones \\ IRTA, PO Box 200, 43540 Sant Carles de la Ràpita, Spain, and Xarxa de referència d'R+D+I en Aqüicultura, \\ Generalitat de Catalunya
}

\begin{abstract}
Between January and April 2000, several experiments were performed during a Karlodinium spp. proliferation in Alfacs Bay (Ebro delta, NW Mediterranean) to determine the effects of these dinoflagellates on sea bream Sparus aurata cultivated in the area. Moribund fish showed an increase in plasma osmolality together with a decrease in the haematocrit percentage compared to control fish. The efficacy of copper sulphate, hydrogen peroxide, potassium permanganate and formalin against Karlodinium spp. was also tested. None of these treatments had mitigation effects when applied in the presence of fish; on the contrary, lethal effects appeared at lower Karlodinium spp. densities compared to fish control groups. When a lytic agent, such as copper sulphate, was used as a water pre-treatment, in the absence of fish, Karlodinium spp. toxicity was significantly reduced. Protocols for water pre-treatments were studied as a potential tool for combating Karlodinium spp. in fish farms.
\end{abstract}

KEY WORDS: Dinoflagellate $\cdot$ Karlodinium armiger $\cdot$ K. veneficum $\cdot$ Harmful algal blooms $\cdot$ HABs $\cdot$ Ichthyotoxic $\cdot$ Mitigation

\section{INTRODUCTION}

Some phytoplankton species cause fish losses in mariculture. A variety of physiological mechanisms, singly or in combination, may lead to fish mortality from harmful algal blooms (HABs). These can be generally categorised as: (1) physical damage or irritation of gill tissue, (2) toxigenic reactions to ichthyotoxic agents, (3) blood hypoxia from environmental oxygen depletion, or (4) gas bubble trauma from oxygen supersaturation (Anderson et al. 2001).

Mitigation to reduce the impacts of HABs includes strategies for avoiding blooms (prevention), such as moving fish cages from the path of a $\mathrm{HAB}$, or actions that directly target the bloom population (control), such as the direct application of chemicals or other biological control agents that kill or disrupt HAB cells during blooms (Anderson et al. 2001).

Karlodinium armiger and $K$. veneficum (Bergholtz et al. 2006) are small, unarmoured dinoflagellates
(15 to $24 \mu \mathrm{m}$ in length, 12 to $18 \mu \mathrm{m}$ in width). K. veneficum (syn. K. micrum, Gyrodinium galatheanum and G. micrum; Daugbjerg et al. 2000, IOC 2002, Bergholtz et al. 2006) has been known since the 1950s to be ichthyotoxic in the South Atlantic (Braarud 1957, Pieterse \& van der Post 1967) and has also been associated with fish kill events in the Murray River/Estuary, Western Australia (Cosgrove et al. 2000), Chesapeake Bay (Terlizzi et al. 2000), South Carolina (Kempton et al. 2002) and Lebanese coastal waters (Abboud-Abi Saab \& ElBakht 1998). In Alfacs Bay (Ebro delta, NW Mediterranean), these organisms were referred to as G. corsicum until recently after a taxonomic study of several strains isolated during fish kill events in 1998 and 2000 (Garcés et al. 2006). For the purpose of this work, we will refer to the 2 species blooming together in Alfacs Bay during the study period as Karlodinium spp. Karlodinium spp. have been producing winter proliferations in the waters of Alfacs Bay since 1994, and the blooms have been associated with massive fish mortalities 
Table 1. Sparus aurata. Water treatments used to eliminate the toxicity of Karlodinium spp.

\begin{tabular}{|c|c|c|c|c|}
\hline $\begin{array}{l}\text { Expt } \\
\text { number }\end{array}$ & $\begin{array}{l}\text { Karlodinium spp. } \\
\text { density (cells } \mathrm{ml}^{-1} \text { ) }\end{array}$ & $\begin{array}{c}\text { Fish size } \\
(\text { mean } \pm \mathrm{SD})\end{array}$ & Treatment & $\begin{array}{l}\text { Type of } \\
\text { treatment }\end{array}$ \\
\hline 1 & 820 & $53.45 \pm 8.14 \mathrm{~g}, 14.50 \pm 0.74 \mathrm{~cm}$ & Copper sulphate & Treatment in presence of fish (Time 0 ) \\
\hline 2 & 700 & $53.45 \pm 8.14 \mathrm{~g}, 14.50 \pm 0.74 \mathrm{~cm}$ & Copper sulphate & Treatment in presence of fish (Time 0) \\
\hline 3 & 963 & $2.23 \pm 0.36 \mathrm{~g}, 5.19 \pm 0.23 \mathrm{~cm}$ & Copper sulphate & Treatment in presence of fish (Time 0 ) \\
\hline 4 & 995 & $53.45 \pm 8.14 \mathrm{~g}, 14.50 \pm 0.74 \mathrm{~cm}$ & Copper sulphate & Treatment in presence of fish (Time 0 ) \\
\hline 5 & 24000 & $2.23 \pm 0.36 \mathrm{~g}, 5.19 \pm 0.23 \mathrm{~cm}$ & Copper sulphate & Kinetic assay \\
\hline 6 & 2197 & $2.23 \pm 0.36 \mathrm{~g}, 5.19 \pm 0.23 \mathrm{~cm}$ & Copper sulphate & Kinetic assay \\
\hline 7 & 2197 & $2.23 \pm 0.36 \mathrm{~g}, 5.19 \pm 0.23 \mathrm{~cm}$ & Copper sulphate & Treatment in presence of fish Time 0 ) \\
\hline 8 & 2197 & $2.23 \pm 0.36 \mathrm{~g}, 5.19 \pm 0.23 \mathrm{~cm}$ & Formalin & Treatment in presence of fish (Time 0 ) \\
\hline 9 & 2197 & $2.23 \pm 0.36 \mathrm{~g}, 5.19 \pm 0.23 \mathrm{~cm}$ & Hydrogen peroxide & Treatment in presence of fish (Time 0) \\
\hline 10 & 2197 & $2.23 \pm 0.36 \mathrm{~g}, 5.19 \pm 0.23 \mathrm{~cm}$ & Potassium permanganate & Treatment in presence of fish (Time 0) \\
\hline 11 & 2197 & $2.23 \pm 0.36 \mathrm{~g}, 5.19 \pm 0.23 \mathrm{~cm}$ & $\begin{array}{l}\text { Copper sulphate }+ \\
\text { hydrogen peroxide }\end{array}$ & Treatment in presence of fish (Time 0) \\
\hline
\end{tabular}

(Delgado et al. 1995). The growth rates measured in Alfacs Bay for Karlodinium spp. (0.39 to $0.94 \mathrm{~d}^{-1}$ ) exceeded the losses by advection $\left(0.12 \mathrm{~d}^{-1}\right)$ during the winter, which generated water discoloration during months when there were no freshwater inputs from the Ebro delta (Garcés et al. 1999).

Lethal effects directly induced by this dinoflagellate have been demonstrated against the co-occurring planktonic copepod Acartia grani (Delgado \& Alcaraz 1999), although the noxious effects were not attributable to toxin intake through ingestion of the dinoflagellate. The relationships between cell densities of natural Karlodinium spp. populations and mortalities of juvenile sea bream Sparus aurata and sea bass Dicentrarchus labrax are of use in the prevention of fish kills by this dinoflagellate in fish farms (Fernández-Tejedor et al. 2004).

The objectives of the present work were to determine the efficacy of different treatments used in aquaculture for mitigation of Karlodinium spp. and, secondly, to monitor the effects on fish during exposure. Mortality, haematocrit (Hc) and plasma osmolality were assessed.

\section{MATERIALS AND METHODS}

The main algal killing agents used in aquaculture were assayed and tested against a mixed population of Karlodinium armiger and $K$. veneficum in the presence of fish. The agents included copper sulphate, formalin, hydrogen peroxide, potassium permanganate and a combination of copper sulphate and hydrogen peroxide. Copper sulphate was also tested both in the presence of fish and before challenge in 2 time series experiments. For time series experiments, fish were introduced in tanks treated with copper sulphate at different periods after the treatment. In total, 11 experiments were performed, and the conditions are shown in Tables 1 and 2. For each experiment, 2 controls were used: one was a control using water free of Karlodinium spp. that was also treated with the same dose of chemical, the second was a control containing Karlodinium spp. but no chemicals.

Water samples containing Karlodinium spp. were obtained directly from Alfacs Bay using a pump. The pumped water was used within 1 to $2 \mathrm{~h}$ to challenge fish in Expts 1 to 4 and 6 to 11. For Expt 5, a $300 \mathrm{~m}^{3}$ concrete pond was used to store water from Alfacs Bay. During the day and in the absence of wind, Karlodinium spp. aggregated and formed visible patches that contained densities significantly higher than in the water from Alfacs Bay. Water was directly pumped from these clusters and employed for challenge.

The Utermöhl method (Utermöhl 1931) was used to determine phytoplankton densities, using 5 and $10 \mathrm{ml}$ HYDRO-BIOS settling chambers. Each sample was settled in triplicate, and 10 fields in each chamber were counted. The average value of the resulting 30 fields was used. Karlodinium spp. were 90 to $99 \%$ dominant in cell numbers for all samples (Fernández-Tejedor et al. 2004).

Experimental animals. Two stocks of juvenile gilthead sea bream Sparus aurata $(53.45 \pm 8.14 \mathrm{~g}, 14.50 \pm$ $0.74 \mathrm{~cm}$ and $2.23 \pm 0.36 \mathrm{~g}, 5.19 \pm 0.23 \mathrm{~cm}$ ) were obtained from 2 different fish farms inside and outside the Ebro delta, respectively. All fish were maintained

Table 2. Water conditions for treatments in Table 1

\begin{tabular}{|lcccc|}
\hline Expt & $\begin{array}{c}\text { Temperature } \\
\left({ }^{\circ} \mathrm{C}\right)\end{array}$ & Salinity & $\begin{array}{c}\text { Oxygen } \\
(\% \text { saturation })\end{array}$ & $\mathrm{pH}$ \\
\hline 1 & $7.90 \pm 1.08$ & $36.15 \pm 0.81$ & $84.12 \pm 4.03$ & $8.12 \pm 0.08$ \\
2 & $8.10 \pm 1.05$ & $36.16 \pm 0.62$ & $85.14 \pm 2.43$ & $8.11 \pm 0.11$ \\
$3,5-11$ & $18.88 \pm 0.17$ & $35.90 \pm 0.14$ & $82.5 \pm 3.11$ & $8.08 \pm 0.09$ \\
4 & $13.90 \pm 1.19$ & $36.53 \pm 0.92$ & $91.25 \pm 2.04$ & $8.14 \pm 0.12$ \\
\hline
\end{tabular}


for 1 mo before experiments in tanks at a density of $5 \mathrm{~kg} \mathrm{~m}^{-3}$ in running water and free of Karlodinium spp.

Gilthead sea bream $(57.78 \pm 10.86 \mathrm{~g}, 14.59 \pm 1.37 \mathrm{~cm})$ were also sampled for plasma osmolality and haematocrit during a natural mortality episode caused by Karlodinium spp. at the same fish farm where the first stock group was obtained 6 wk previously.

Environmental water conditions during challenge. To exclude temperature effects, the water temperature in experimental tanks was maintained at the same level as the temperature in the natural environment from which the Karlodinium spp. containing water was received. The temperature of Expts 1, 2 and 4 was the same as the origin of the sample, and unwanted effects related to thermal influences were avoided by maintaining the fish stock at the same temperature measured in the Bay. For Expts 3 and 5 to 11 , the temperature of the water containing Gyrodinium corsicum was raised to $18.88 \pm 0.17^{\circ} \mathrm{C}$ by leaving the sample in glass beakers until room temperature was reached. Temperature, salinity, percentage oxygen saturation and $\mathrm{pH}$ values were monitored every $2 \mathrm{~h}$ (Table 2). All treatments were continuously aerated both to keep the fish alive and also to improve cell lyses by the chemicals.

Choice of chemical concentration for water treatment. The ranges of chemical concentrations were based on the doses recommended by Brown (1993). The following doses were chosen for the main experiments: $0.4 \mathrm{mg} \mathrm{l}^{-1}$ for copper sulphate, $0.7 \mathrm{mg} \mathrm{l}^{-1}$ for potassium permanganate, $8 \mathrm{mg} \mathrm{l}^{-1}$ for formaldehyde and $300 \mathrm{mg} \mathrm{l}^{-1}$ for hydrogen peroxide.

Chemical application. Two approaches were undertaken: the use of the chemical in the presence of fish and Karlodinium spp. at the same time (Time 0) and a kinetic assay for the chemical treatment of the water containing Karlodinium spp. before the immersion of fish. Duplicate groups of 5 juvenile gilthead sea bream from the 2 different stocks were placed either in 501 tanks (Expts 1, 2 and 4) or 2.51 glass beakers (Expts 3 and 5 to 11). Expts 1 to 4 consisted of duplicate tanks with water containing Karlodinium spp. treated with copper sulphate, a sample containing Karlodinium spp. without treatment and a control with only copper sulphate. Expt 5 (19 February 2000) and Expt 6 (29 March 2000) consisted of adding copper sulphate to all beakers containing the same density of Karlodinium spp. at the same time and adding 5 fish per beaker in duplicate at different times $(0,0.5,1$, 3, 6 and $12 \mathrm{~h}$ for Expt 5; 0, 1, 3, 6 and $12 \mathrm{~h}$ for Expt 6). Expts 7 to 11 consisted of treatments of copper sulphate, formalin, hydrogen peroxide, potassium permanganate and copper sul- phate plus hydrogen peroxide, respectively, all of them at the same Karlodinium spp. density as Expt 6. Negative controls were performed using filtered Mediterranean seawater free of Karlodinium spp.

Fish behaviour was monitored at all times. Fish showing no operculum movement were removed from the beaker, and the time of death was recorded. The experiment lasted $48 \mathrm{~h}$, after which time the final number of dead and live fish was recorded. In addition to the fish mortality results for the different treatments, certain blood parameters were assayed when experimental conditions and fish size allowed. Hc values and mortalities were recorded in Expts 3, 4 and 5. Plasma osmolality values and mortalities were recorded in experiments 1, 2 and 4 .

Blood sampling. When fish size $(53.45 \pm 8.14 \mathrm{~g}$, $14.50 \pm 0.74 \mathrm{~cm}$ and $57.78 \pm 10.86 \mathrm{~g}, 14.59 \pm 1.37 \mathrm{~cm}$ ) allowed, blood samples were taken from a caudal peduncle puncture, with a heparin-treated disposable plastic syringe, and collected in both heparinised microhaematocrit tubes and heparinised Eppendorf centrifuge tubes. Sodium heparin was used as an anticoagulant. Blood was stored immediately in an ice bath. For smaller sea bream $(2.23 \pm 0.36 \mathrm{~g}, 5.19 \pm$ $0.23 \mathrm{~cm}$ ), the caudal peduncle was cut off for collection directly into a haematocrit tube.

Haematological parameters. Hc values (percent packed cell volume) were determined using a microhaematocrit centrifugation technique (Heraeus Biofuge haemo) immediately after blood collection. Blood samples for plasma chemical studies were centrifuged in Eppendorf centrifuge tubes at $1000 \times g$ for 20 min at $4^{\circ} \mathrm{C}$ (Eppendorf centrifuge 5415D). The plasma was then separated from the cells and stored at $-80^{\circ} \mathrm{C}$ until it could be analysed. Plasma osmolality was determined by the freezing point method using a microosmometer (Advanced Instruments, 3MO).

Statistics. For comparison of percentage mortalities, a chi-squared test was used. For comparison of osmolality and haematocrit values between groups, a $t$-test, Mann-Whitney and Kruskal-Wallis tests were used. Statistically significant differences between groups were considered when $\mathrm{p}<0.05$.

Table 3. Sparus aurata. Summarised mortality results (corresponding to Expts 1 to 4 )

\begin{tabular}{|c|c|c|c|c|}
\hline \multirow[t]{2}{*}{ Expt } & \multicolumn{3}{|c|}{$\longrightarrow$ Mortality (\%) } & \multirow[t]{2}{*}{ Cells ml ${ }^{-1}$} \\
\hline & $\begin{array}{l}\text { Karlodinium spp. } \\
\quad+\mathrm{CuSO}_{4}\end{array}$ & $\begin{array}{c}\text { Control water } \\
+\mathrm{CuSO}_{4}\end{array}$ & $\begin{array}{l}\text { Karlodinium } \\
\text { spp. }\end{array}$ & \\
\hline 1 & $100 \pm 0$ & 0 & 0 & 820 \\
\hline 2 & $80 \pm 28$ & 0 & 0 & 700 \\
\hline 3 & $100 \pm 0$ & 0 & 0 & 963 \\
\hline 4 & $70 \pm 14$ & 0 & 0 & 995 \\
\hline
\end{tabular}



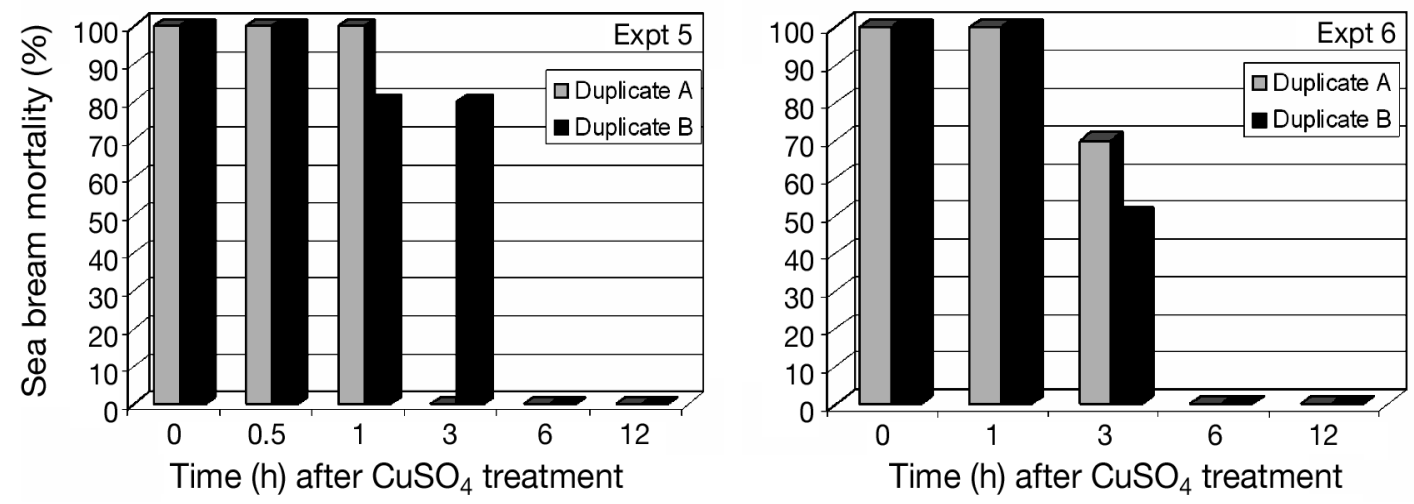

Fig. 1. Sparus aurata. Percentage of fish mortalities after exposure to water containing Karlodinium spp. pre-treated with copper

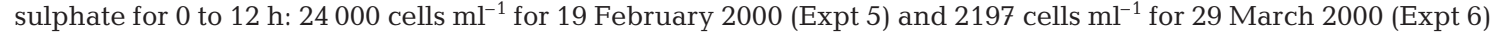

\section{RESULTS}

\section{Treatments}

All Sparus aurata challenged with Karlodinium spp. at densities lower than 1000 cells $\mathrm{ml}^{-1}$ survived after $48 \mathrm{~h}$ of exposure (Table 3). However, mortalities ranged from 70 to $100 \%$ when copper sulphate was added to the tanks at Time 0 . There were no significant differences between the percentage mortalities registered in Expts 1 to $4(H=4.5, \mathrm{p}=0.419)$.

In Expts 5 and 6, kinetic studies were performed by adding Sparus aurata at different times to the tanks containing Karlodinium spp. and copper sulphate. Fish mortalities ranged from $100 \%$ at Time 0 in both experiment to $0 \% 6 \mathrm{~h}$ after exposure (Fig. 1). Control groups for the copper sulphate treatment had $100 \%$ fish survival.

For the different treatment assays, 100\% mortality was produced in Expts 7 to 11, when fish were challenged with copper sulphate, formalin, hydrogen peroxide and potassium permanganate, whereas the respective control treatments showed $0 \%$ mortality. Only application of copper sulphate plus hydrogen peroxide reduced fish mortality to $0 \%$ after $48 \mathrm{~h}$ of immersion. These treatments were applied in water containing 2197 Karlodinium spp. cells $\mathrm{ml}^{-1}$.

\section{Haematological parameters}

After challenge with Karlodinium spp., higher osmolality (Fig. 2) values were measured in plasma from moribund fish compared to survivors and control fish (no Karlodinium spp. present), both when copper sulphate had been added to the system or in copper sulphate-free water (Expts 1, 2 and 4). The experimental conditions are detailed in Tables 1 \& 2.
There was a significant difference between the osmolality medians of moribund and control fish (no Karlodinium spp. present) in each experiment (1,2 and 4) $(t=2.890, \mathrm{p}=0.01 ; t=3.532, \mathrm{p}=0.006 ; t=8.603 \mathrm{p} \leq$ 0.001). In Expt 4, there was a significant difference between moribund and surviving fish independently of whether copper sulphate had been added to the glass beakers $(F=47.281, \mathrm{p}<0.001)$. Moreover, in Expt 4 , no significant differences in osmolality values were found between any of the 3 surviving fish groups ( $F=$ $0.167, \mathrm{p}=0.847$ ). No significant differences were found between moribund fish from Expts 1,2 and 4 ( $F=$ 2.808, $\mathrm{p}=0.080$ ).

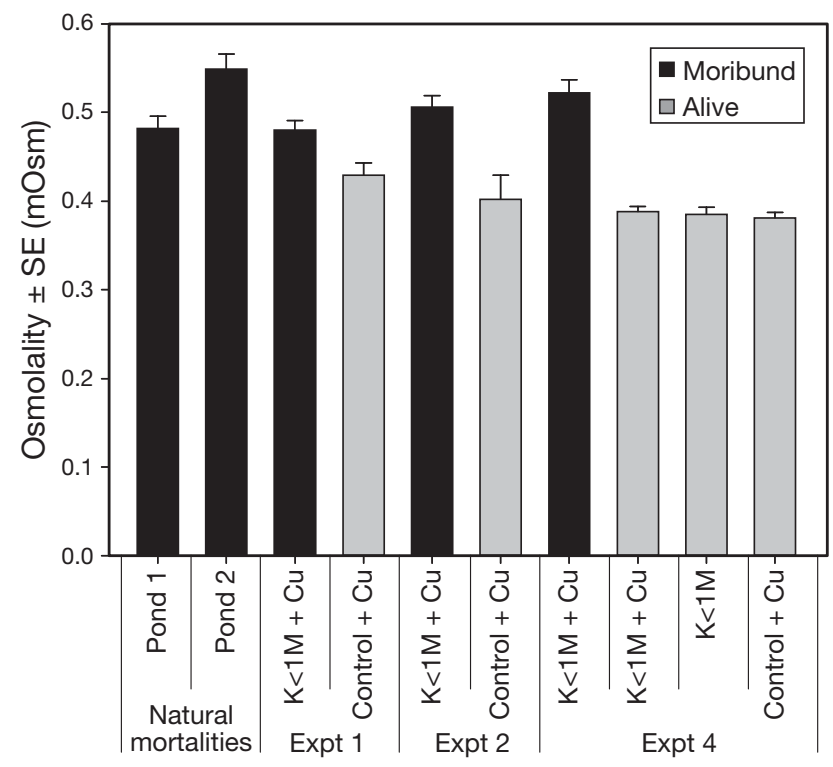

Fig. 2. Sparus aurata. Osmolality values (mean and SE) for fish exposed to water treated with copper sulphate $(\mathrm{Cu})$ containing Karlodinium spp. $\left(\mathrm{K}_{i}<1 \mathrm{M}\right.$ : cell density $<1000$ cells ml$\left.^{-1}\right)$ and a control for Expts 1 and 2. For Expt 4, values include a control of non-treated water containing Karlodinium spp. $\mathrm{n}=10$ 


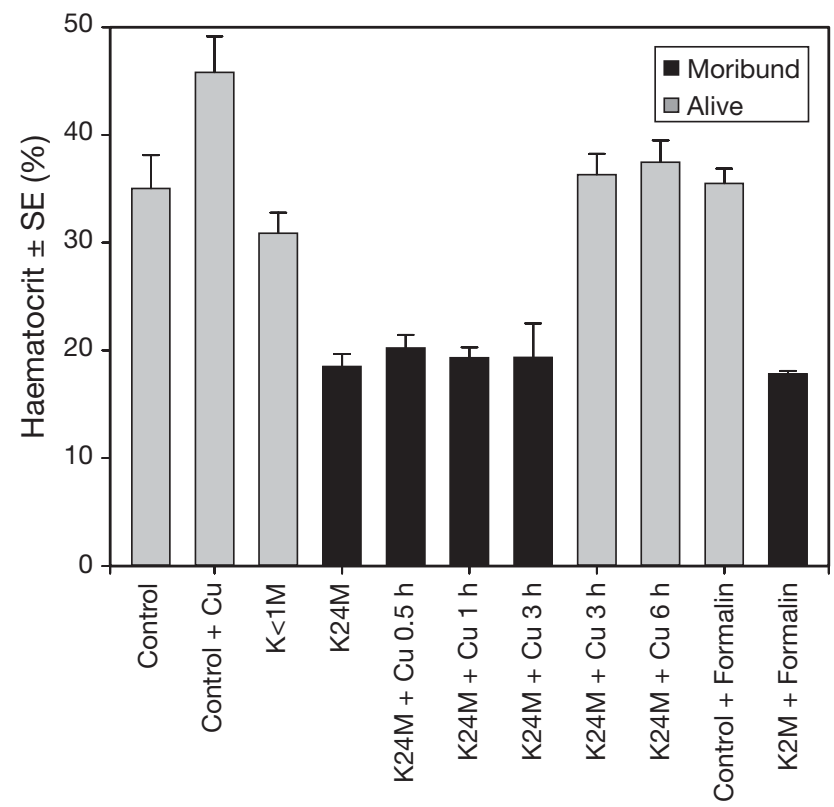

Fig. 3. Sparus aurata. Haematocrit values (mean and SE) for moribund, alive and control fish after immersion in copper sulphate $(\mathrm{Cu})$ pre-treated water containing Karlodinium spp. $\left(\mathrm{K}_{\text {; }}\right.$ $<1 \mathrm{M}$ : $<1000$ cells ml ${ }^{-1}$; 24M: 24000 cells ml ${ }^{-1}$; $2 \mathrm{M}$ : $\sim 2000$ cells $\mathrm{ml}^{-1}$ ) and after a formalin treatment of the same water sample

When moribund fish from a nearby aquaculture facility were sampled (see 'Materials and methods') during an episode of mortalities due to Karlodinium spp., plasma osmolality values in pond 1 were similar to moribund fish in Expts 1,2 and $4(F=2.176, \mathrm{p}=$ 0.110 ), and values in Pond 2 were similar to moribund fish in Expts 2 and $4(F=2.199, \mathrm{p}=0.136)$.

It was not possible to obtain plasma from unexposed fish at the fish farm. However, plasma from the control fish in Expts 1 and 2 could be considered a negative control (no Karlodinium spp. present), since both fish stocks and water parameters were equivalent for experimental groups and cultured fish.

Hc was reduced in fish exposed to Karlodinium spp. (Fig. 3) compared to the control group. In Expts 5 and 6 , copper sulphate produced a non-significant increase in Hc $(45.80 \pm 3.35 \%)$, while formalin $(35.50 \pm 1.35 \%)$ did not change the Hc values compared to control values $(35.04 \pm 3.09 \% ; t=-1.954 \mathrm{p}=0.077 ; t=-0.0976, \mathrm{p}=$ $0.927,95 \%)$. When fish were exposed to Karlodinium spp. and copper sulphate was added at different times for water pre-treatment (see 'Materials and methods'), there were no significant differences in the Hc values between groups of moribund fish $(F=0.338, \mathrm{p}=0.798$, $95 \%)$. Hc values from moribund fish in Expt 5 combining all copper sulphate-treated groups together were significantly different from the control $(t=-7.45, \mathrm{p} \leq$ $0.001,95 \%)$, the copper sulphate-treated control $(t=$ $342, \mathrm{p} \leq 0.001,95 \%$ ) and the group exposed to a sub- lethal density of Gyrodinium corsicum $(t=-7,037$, $\mathrm{p} \leq$ $0.001,95 \%$ ). There were no significant differences in the Hc values between moribund fish in Karlodinium spp. water treated with copper sulphate (Expt 5) or with formalin (Expt $6 ; t=-0.515, \mathrm{p}=0.610,95 \%$ ). The highest Hc values recorded in the experiments using Sparus aurata were found in the control group treated with copper sulphate $(45.90 \pm 3.35 \%)$. The lowest values were observed in moribund fish in water containing Karlodinium spp. (2197 cells ml ${ }^{-1}$ ) treated with formalin $(17.81 \pm 0.27 \%)$. The Hc values of all moribund fish in Expt 5 formed a homogeneous group, which was significantly different from the survivors $(t=$ -13.289, p $\leq$ 0.001, 95\%). In Expt 5, Karlodinium spp. produced a decrease in Hc when it was associated with fish mortality, but this reduction in Hc values was not observed at sublethal densities of the dinoflagellate both in comparison to control values $(t=7.457, \mathrm{p} \leq$ $0.001 ; t=1.224, \mathrm{p}=0.252$, respectively, $95 \%$ ).

\section{DISCUSSION}

The recorded Karlodinium spp. densities in Alfacs Bay for 20 spring days in 2000 were higher than the lowest experimental LD $_{50}$ (Fernández-Tejedor et al. 2004). As a result, intensive monitoring was established at a fish farm to determine the levels of Karlodinium spp. in the water intake every $30 \mathrm{~min}$. However, because this system allowed Karlodinium spp. to be detected, high densities entering in clusters could be avoided. For a sustained presence of Karlodinium spp. over a long period, a mitigation protocol was required to manage the toxic algae at the fish farms in Alfacs Bay.

We measured higher Hc values in fish immersed in water treated with copper sulphate. The Hc is considered one of the good stress indicators that are variously affected in fish (Soivio \& Oikari 1976, Wilson \& Taylor 1993, Roche \& Bogé 1996). The Hc decreases after intoxication by organic compounds and increased after metallic intoxication. Roche \& Bogé (1996) found that the higher values in sea bass intoxicated with metallic compounds resulted from an increased cell volume because no change in blood haemoglobin was shown. Our results agree with these observations. Hc values found in moribund fish after exposure to non-treated and formalin-treated water containing Karlodinium spp. (2197 cells ml ${ }^{-1}$ ) were lower than those measured in moribund fish after copper sulphate treatment, although the difference was not significant. Control water treated with copper sulphate produced higher Hc values in fish after a $48 \mathrm{~h}$ exposure compared to values measured in non-treated and formalin-treated control water. 
Changes in osmolality from $429 \pm 14$ to $480 \pm 11 \mathrm{mOsm}$ in Expt 1, from $402 \pm 27$ to $506 \pm 13$ mOsm in Expt 2 and from $381 \pm 6$ to $522 \pm 15$ mOsm in Expt 4 were similar to those found when juvenile cod Gadus morhua were exposed to a culture of Karlodinium veneficum $\left(115 \times 10^{6}\right.$ cells $\left.1^{-1}\right)$; the fish showed an increased plasma osmolality (Nielsen 1993) from $336 \pm 6$ mOsm ( $\mathrm{n}=10)$ to $444 \pm 8$ mOsm $(\mathrm{n}=10)$ before death. A similar effect on plasma chloride was postulated when exposing Atlantic salmon Salmo salar and rainbow trout Oncorhynchus mykiss to the toxic alga Chrysochromulina polylepis (Leivestad \& Serigstad 1989). The toxins may increase the permeability of the fish gill in these cases.

The same effect resulting in greater mortality when a lytic agent was used to treat an ichthyotoxic bloom has been observed for Karlodinium veneficum in Chesapeake Bay, USA (Deeds et al. 2002, 2004). These authors discovered a substance that is ichthyotoxic, cytotoxic and haemolytic and appears to be released in small amounts in healthy cultures, but is released in greater amounts upon cell damage or lysis. Deeds et al. (2002) found that the addition of potassium permanganate $\left(4 \mathrm{mg} \mathrm{l}^{-1}\right)$ to $K$. veneficum cells and culture filtrates, as well as to the haemolytic HPLC fractions Tox A (KmTx1) and Tox B, resulted in the complete disappearance of haemolytic activity. Toxicity was eliminated after potassium permanganate $\left(4 \mathrm{mg} \mathrm{l}^{-1}\right.$ ) treatment. In contrast, in our experiment, potassium permanganate treatment increased mortality. However, we used a much lower concentration of chemical $\left(0.7 \mathrm{mg} \mathrm{l}^{-1}\right)$ because higher concentrations killed sea bream under our test conditions. Potassium permanganate is an oxidant, and the dose used by Deeds et al. (2002) was sufficient to lyse dinoflagellate cells, oxidise the toxin and avoid fish mortalities during the $K$. veneficum bloom in Chesapeake Bay. The toxins isolated from $K$. veneficum have been called karlotoxins, and their mode of action seems to be the increase in membrane permeability, resulting in cell death; for example, KmTx2 increases membrane ionic permeability equally for a range of mammalian cell types (Deeds et al. 2006), and KmTx1 causes the release of the cytosolic marker lactate dehydrogenase in rat pituitary tumour cells, suggesting cell lysis (Deeds et al. 2002).

The reduction in fish mortality to $0 \%$ using the treatment of copper sulphate plus hydrogen peroxide is probably due to the lysis of dinoflagellate cells by copper sulphate and toxin inactivation by hydrogen peroxide. Nevertheless, our results indicate that a pretreatment with 2 successive applications of hydrogen peroxide or a unique application at a higher dose could probably reduce the waiting time for diminution of its lethal effects before the immersion of fish in the same water.
This study was undertaken with a natural population of Karlodinium armiger and $K$. veneficum. Several strains were isolated at different times during a bloom. $K$. armiger strains are more toxic than $K$. veneficum strains (Garcés et al. 2006). Toxic compounds from $K$. veneficum have been isolated and characterised (Deeds et al. 2006), but we do not know if $K$. armiger produces the same toxic compounds. Research will continue to determine the chemical structure of the toxin or toxins implicated in both species present in Alfacs Bay.

Acknowledgements. This work was financed by the Centre de Referència en Aqüicultura-Generalitat de Catalunya.

\section{LITERATURE CITED}

Abboud-Abi Saab M, El-Bakht Y (1998) Dominant and potentially toxic microalgae in Lebanese coastal waters. In: Reguera B, Blanco J, Fernández ML, Wyatt T (eds) Harmful algae. Xunta de Galicia and Intergovernmental Oceanographic Commission of UNESCO

Anderson DM, Andersen P, Bricelj VM, Cullen JJ, Rensel JE (2001) Monitoring and management strategies for harmful algal blooms in coastal waters. APEC \#201-MR-01.1. Asia Pacific Economic Program, Singapore, and Intergovernmental Oceanographic Commission Tech Ser No. 59, Paris

Bergholtz T, Daugbjerg N, Moestrup Ø, Fernández-Tejedor M (2006) On the identity of Karlodinium veneficum and description of Karlodinium armiger sp. nov. (Dinophyceae), based on light and electron microscopy, nuclearencoded LSU rDNA, and pigment composition. J Phycol 42:170-193

Braarud T (1957) A red water organism from Walvis Bay (Gymnodinium galatheanum n. sp.). 'Galathea' Rep 1: $137-138$

Brown L (1993) Aquaculture for veterinarians: fish husbandry and medicine. Pergamon Press, Oxford

Cosgrove J, Grigo S, Hosja W, Hallegraef G (2000) The investigation of a dinoflagellate associated with a fish kill event in the Murray River/Estuary, Western Australia. Proc 9th Int Conf Harmful Algal Blooms, Tasmania, p 103 (Abstract)

Daugbjerg N, Hansen G, Larsen J, Moestrup Ø (2000) Phylogeny of some of the major genera of dinoflagellates based on ultrastructure and partial LSU rDNA sequence data, including the erection of 3 new genera of unarmoured dinoflagellates. Phycologia 39:302-317

Deeds JR, Terlizzi DE, Adolf JE, Stoecker DK, Place AR (2002) Toxic activity from cultures of Karlodinium micrum (= Gyrodinium galatheanum) (Dinophyceae)-a dinoflagellate associated with fish mortalities in an estuarine aquaculture facility. Harmful Algae 1:169-189

Deeds JR, Mazzaccaro AP, Terlizzi DE, Place AR (2004) Treatment options for the control of the ichthyotoxic dinoflagellate Karlodinium micrum in an estuarine aquaculture facility: a case study. In: Hall S, Etheridge S, Anderson D, Kleindinst J, Zhu M, Zou Y (eds) Harmful algae management and mitigation. APEC Publication No. 204-MR-04.2, Asia-Pacific Economic Cooperation, Singapore, p 177-181

Deeds JR, Reimschuessel R, Place AR (2006) Histopathological effects in fish exposed to the toxins from Karlodinium micrum. J Aquat Anim Health 18:136-148

Delgado M, Alcaraz M (1999) Interactions between red tide 
microalgae and herbivorous zooplankton: the noxious effects of Gyrodinium corsicum (Dinophyceae) on Acartia grani (Copepoda: Calanoida). J Plankton Res 21:2361-2371

Delgado M, Fernández JV, Garcés E, Matamoros E, Camp J (1995) Proliferación de un dinoflagelado del género Gyrodinium en la bahía de Alfacs (Delta del Ebro) asociado a mortandad de peces. In: Cartelló F, Calderer A (eds) Actas del V Congreso Nacional de Acuicultura. Universidad de Barcelona, p 700-704

Fernández-Tejedor $M$, Soubrier-Pedreño MA, Furones MD (2004) Acute $\mathrm{LD}_{50}$ of a Gyrodinium corsicum natural population for Sparus aurata and Dicentrarchus labrax. Harmful Algae 3:1-9

Garcés E, Delgado M, Masó M, Camp J (1999) In situ growth rate and distribution of the ichthyotoxic dinoflagellate Gyrodinium corsicum Paulmier in an estuarine embayment (Alfacs Bay, NW Mediterranean Sea). J Plankton Res 21:1977-1991

Garcés E, Fernandez M, Penna A, Van Lenning K, Gutiérrez A, Camp J, Zapata M (2006) Characterization of NW Mediterranean Karlodinium spp. (Dinophyceae) strains using morphological, molecular, chemical and physiological methodologies. J Phycol 42:1096-1112

IOC (Intergovernmental Oceanographic Commission of UNESCO) (2002) Taxonomic reference list of toxic algae. Available at: www.bi.ku.dk/ioc/

Kempton JW, Lewitus AJ, Deeds JR, McHugh Law J, Place AR (2002) Toxicity of Karlodinium micrum (Dinophyceae) associated with a fish kill in a South Carolina brackish retention pond. Harmful Algae 1:233-241

Leivestad H, Serigstad B (1989) ICES Workshop. Properties of

Editorial responsibility: Thomas Braunbeck, Heidelberg, Germany
Chrysochromulina polylepis. The Chrysochromulina polylepis bloom in the Skagerrak and the Kattegat in MayJune 1988: environmental conditions, possible causes and effects. In: Skjoldal HR, Dundas I (eds) Cooperative Research Report. International Council for the Exploration of the Sea, Copenhagen

Nielsen MV (1993) Toxic effect of the marine dinoflagellate Gymnodinium galatheanum on juvenile cod Gadus morhua. Mar Ecol Prog Ser 95:273-277

Pieterse F, van der Post DC (1967) The pilchard of South West Africa. Oceanographical conditions associated with red tides and fish mortalities in the Walvis Bay region. Investig Rep Mar Res Lab SW Afr 14:1-125

Roche H, Bogé G (1996) Fish blood parameters as a potential tool for identification of stress caused by environmental factors and chemical intoxication. Mar Environ Res 41: $27-43$

Soivio A, Oikari A (1976) Haematological effects of stress on a teleost, Esox lucius L. J Fish Biol 8:397-411

Terlizzi DE, Stoecker D, Glibert PM (2000) Gyrodinium galatheanum: a threat to estuarine aquaculture. Responsible aquaculture in the new millennium. In: Flos R, Creswell L (eds) Abstracts of contributions presented at the International Conference AQUA 2000, Nice, France, May 2-6, 2000. European Aquaculture Society Special Publication No. 28, Oostende

Utermöhl H (1931) Neue Wege in der quantitativen Erfassung des Planktons. Verh Int Ver Limnol 5:567-596

Wilson RW, Taylor EW (1993) The physiological responses of freshwater rainbow trout, Oncorhynchus mykiss, during acutely lethal copper exposure. J Comp Physiol 163B:38-47

Submitted: September 30, 2006; Accepted: May 2, 2007

Proofs received from author(s): July 31, 2007 